\author{
Ante Jerić \\ Sveučilište u Rijeci, Filozofski fakultet, Sveučilišna avenija 4, HR-51000 Rijeka \\ ante.jeric@uniri.hr
}

\title{
Na rubu igrivosti: egzistencija i transcendencija u filmu eXistenZ
}

\section{Sažetak}

Filozofija i znanstvena fantastika kao različiti diskursi na različite načine koriste protuintuitivne scenarije. Filozofija nastupa fundacijski u pokušaju utemeljivanja protuintuitivnih scenarija i dokazivanja njihove koherentnosti, dok znanstvena fantastika kao transmedijalni fikcionalni žanr pretpostavlja njihovu koherentnost $i$ nastupa pragmatički prilikom pripovijedanja o tome kako bi to bilo kad bi se oni obistinili. Ovaj rad posvećen je analizi znanstveno-fantastičnog filma Davida Cronenberga eXistenZ (1999). U njemu branim dvije teze. Kritičko-teorijska teza: Cronenberg smatra da život u kasnom kapitalizmu biva organiziran sukladno logici igre, predočava tu logiku ovim fikcionalnim scenarijem i prokazuje je kao nepoželjnu. Metafizička teza: Cronenbergov dijegetski svijet donosi novu, iako ne originalnu, artikulaciju skepticizma kao starog filozofskog problema. Pokušaj fundiranja metafizičkih pretpostavki ovog dijegetskog svijeta reanimira kartezijanski interakcionistički dualizam i kantovski transcendentalni idealizam kao dvije dobro poznate i utvrđene filozofske pozicije.
\end{abstract}

\section{Ključne riječi}

znanstvena fantastika, misaoni eksperiment, David Cronenberg, skepticizam, slobodna volja, interakcionistički dualizam, transcendentalni idealizam

\section{Uvod}

Prvi scenarij: zamislimo da živimo u savršenoj računalnoj simulaciji. Kako bismo uopće mogli spoznati prirodu naše stvarnosti? Jesmo li oduvijek bili u simulaciji ili nas je netko bez našeg znanja u nju učitao? Kako bismo se osjećali i što bismo učinili jednom kad bismo u to posumnjali? Drugi scenarij: zamislimo da nemamo slobodnu volju. Kako bismo uopće došli na tu ideju? Zašto mislimo da imamo slobodnu volju ako je, zapravo, nemamo? Tko je onda u konačnici, ako mi već nismo, odgovoran za naše postupke? Većina ljudi misli kako nije vjerojatno da živimo u simulaciji i da nemamo slobodnu volju. Potonji scenariji suprotstavljeni su našim najdubljim uvjerenjima i možemo ih okvalificirati kao protuintuitivne. Protuintuitivni scenariji obično nemaju praktične posljedice za naše živote i zbog toga nisu čest predmet razgovora. No postoje diskursi unutar kojih se protuintuitivni scenariji shvaćaju ozbiljno i unutar kojih se na pitanja s početka ovog teksta, koja obično ne postavljamo, daju promišljeni i detaljni odgovori. Radi se o filozofiji i znanstvenoj fantastici. Filozofija i znanstvena fantastika kao različiti diskursi na različite načine koriste protuintuitivne scenarije. Filozofija ih, kako kaže Steven Shaviro (2016), pokušava utemeljiti i na toj osnovi doći do netrivijalnih zaključaka, dok znanstvena fantastika pretpostavlja njihovu utemeljenost i koherentnost te pragmatički istražuje kako bi to bilo kad bi se oni obistinili. ${ }^{1}$ 
U ovom radu razmatram znanstveno-fantastični film eXistenZ (1999) Davida Cronenberga kao alegorijski tekst $\mathrm{s}$ dvije značenjske razine - doslovnom $\mathrm{i}$ prenesenom. Rad obrađuje dvije teme, vezane uz navedene razine, te ima tri cilja:

A) eXistenZ predstavlja kritiku društva u kojem je nastao. Na prenesenoj značenjskoj razini, on je zanimljiv kao artikulacija straha prisutnog kod svoje publike. Što su to ljudi na prijelazu milenija doživljavali kao prijetnju? Postupnu gamifikaciju društva. Kasni kapitalizam kao društveno-ekonomska matrica od subjekata traži internalizaciju logike igara: navikavanje na neslobodu, ograničavanje mogućih poteza, odabir samo onih rješenja koja omogućuju napredovanje. To nikad nisu bili samo načini savladavanja problema u igri, već i zahtjevi koje društveni život u sve većoj mjeri nameće pojedincu. Prvi je cilj teksta pokazati kako Cronenberg smatra da život u kasnom kapitalizmu biva organiziran sukladno logici igre, da predočava tu logiku i da je, u konačnici, oštro kritizira. Drugi je cilj teksta pokušaj da se istaknuti motiv u filmu - privremena suspenzija slobodne volje likova u okviru dijegetskog svijeta - prihvati kao poticaj za raspravu o naravi slobodne volje onkraj tog dijegetskog svijeta, te da se posljedično utvrdi da je taj svakodnevni pojam duboko problematičan.

B) Cronenbergov film naš strah od novog tipa društvenog ustroja povezuje sa starim »filozofskim《 strahovima. Na doslovnoj značenjskoj razini on je zanimljiv kao scenarij pomoću kojega je zamišljeno kako bi to bilo kada bi ljudi otkrili da narav stvarnosti nije onakva kakvom su je smatrali. U dijegetskom svijetu eXistenZa, likovi postupno otkrivaju da nisu sigurni kakva je narav svijeta kojim se kreću, odnosno da možda žive u simulaciji. Treći je cilj teksta, sukladno rečenome, eksplicirati metafizičke pretpostavke Cronenbergova scenarija vezane uz narav stvarnosti - kartezijanski interakcionistički dualizam i jedan vid kantovskog transcendentalnog idealizma - te time ukazati na potencijalnu korist eXistenZa za suvremene filozofske rasprave. ${ }^{2}$

\section{Odnos filozofije i znanstvene fantastike}

Razmotrimo kako iz perspektive filozofije izgleda odnos između filozofije i znanstvene fantastike. Filozofija će obično instrumentalizirati znanstvenu fantastiku, pri čemu će se automatski reaktivirati mnoge implicitne hijerarhije između ova dva diskursa. To je neupitno s obzirom na našu pretpostavku. No nas trenutno ne zanima sama opravdanost instrumentalizacije, već njezini modusi.

\subsection{Znanstvena fantastika kao pedagoški alat}

Filozofija je sklona instrumentalizirati umjetnosti kao sredstvo za »ilustriranje « vlastitih teza, pri čemu se, kako podsjeća Luka Bekavac, odmah otvara naročito težak problem, a to je pitanje »odnosa čiste ideje i njezina osjetilnog uprizorenja « (Bekavac, 2016:2). Po ovom modusu instrumentalizacije, znanstvena fantastika samo ilustrira ili čini prijemčivijim ideje koje je moguće bolje i preciznije izraziti u okviru filozofske rasprave. Ljudi koji nisu inicirani u filozofiju i nemaju potrebno predznanje za praćenje apstraktne rasprave mogu pojmiti neke njezine aspekte ako ih se uobliči i konkretizira u obliku zanimljive znanstveno-fantastične priče. Znanstvena fantastika bi, dakle, 
bila pedagoško pomagalo: način da se filozofske ideje priopće nefilozofima. Slijedeći ovaj rezon, mogli bismo zaključiti da filozofi - barem oni dobro verzirani svojoj domeni - ne trebaju priče, budući da mogu izravno prijeći na apstraktnu argumentaciju koja čini bit filozofiranja. Pretpostavimo da znamo $\check{c}$ emu znanstvena fantastika služi - ilustriranju. Znamo li kako ona ispunjava svoju svrhu?

Znanstveno-fantastičnim scenarijima, kako književnim tako i filmskim, filozofi i teoretičari u najširem smislu najčešće pristupaju alegorijski, odnosno krećući od pretpostavke da doslovni sadržaj upućuje na preneseni sadržaj teksta - shvaćenog u najširem smislu - koji ne smijemo previdjeti jer ćemo u suprotnom promašiti njegov smisao. ${ }^{3}$ Pretpostavlja se da znanstveno-fantastični svjetovi - fikcionalni svjetovi »alternativni autorovoj iskustvenoj okolini« (Suvin, 2010:41), čije karakteristike ne možemo ovjeriti ni zdravim razumom ni osjetilima - upućuju na naš svijet, odnosno na zbivanja u njemu. Bit će korisno zadržati se nakratko na pojmu alegorije i razmotriti koga ona, i na koji način, zapravo obvezuje.

Alegoriju možemo razlikovati ovisno o tome kome u komunikacijskom lancu pridamo prvenstvo:

a) Alegoriju možemo vezati uz autora, smatrajući da alegorijski tekstovi unaprijed moraju biti zamišljeni takvima te da moraju sadržavati neku vrstu upute $\mathrm{u}$ vlastito tumačenje. Ako krenemo tim smjerom, morali bismo ustvrditi da su alegorija kao autorova kreacija i alegorija kao recipijentovo tumačenje nužno uzajamno ovisni i međusobno spregnuti. Sukladno tome, alegoriju bismo mogli odrediti kao autorov postupak kojim se u paralelni suodnos dovode doslovna razina značenja i prenesena razina značenja. U našem slučaju, svaki konkretni znanstveno-fantastični scenarij upućivao bi na naš svijet, pri čemu bi gotovo svim bitnim elementima s doslovne razine značenja - likovima i odnosima među njima - odgovarali pripadajući elementi na prenesenoj razini značenja. Dobar primjer alegorije skrojene po ovom obrascu u okviru žanra znanstvene fantastike bio bi film Dan kad je Zemlja stala (The Day the Earth Stood Still, 1951). Djelo Roberta Wisea nazvano je »jedva prikrivenom pričom o Kristovu životu« (Sanders, 2008:4). Ta se teza doima opravdanom: protagonist filma tuđinski je izaslanik imena Klaatu, a njegova je misija uspostavljanje kontakta sa

»Filozofska argumentacija i znanstveno eksperimentiranje pokušavaju dokazati i utemeljiti svoje tvrdnje, koliko god se one u prvi mah doimale protuintuitivnim. Znanstvena fantastika također predlaže protuintuitivne scenarije, no ona prvenstveno nastoji razraditi najčudnije i najekstremnije ramifikacije ovih scenarija i zamisliti kako bi to bilo da su one istinite. Filozofija tim ramifikacijama pristupa fundacijski, a znanstvena fantastika pragmatički i istraživački.« (Shaviro, 2016:9)

Ne tvrdim da nam eXistenZ nudi originalnu perspektivu na metafizičke probleme. Mislim da bi, u kontekstu povijesti ideja, vrlo malo strogo filozofskih rasprava, a kamoli fikcionalnih tekstova, moglo udovoljiti ovom zahtjevu.
Pojam alegorije semantički je iznimno bremenit i nemoguće bi bilo pobrojati i sistematizirati sve njegove upotrebe u okviru ovog teksta. Najopćenitije: u okviru znanosti o književnosti, o alegoriji se govori kao o figuri, tumačenju i književnoj vrsti. Moje korištenje pojma prilično je slobodno i približava se svakodnevnoj, 'neakademskoj' upotrebi. Za potrebe ovog teksta, alegorijom ću smatrati svako djelo u kojem recipijenti prepoznaju postojanje dviju vrsta značenjskih razina: doslovne i prenesene. Čitatelja koji želi 'punokrvno' teorijsko određenje pojma i osvrt na položaj alegorije kao književne vrste u modernom razdoblju upućujem na studiju Pavla Pavličića Moderna alegorija (2013). 
Zemljanima i prijenos poruke o izboru koji im predstoji: ljudi se mogu nastaviti ponašati kao dosad i propasti ili se obratiti, pridružiti njegovoj vrsti u međuplanetarnom savezu i započeti s izgradnjom bolje budućnosti. Klaatu se predstavlja kao 'Carpenter' (Drvodjelja), posjeduje znanje koje nadilazi ljudsko, prijateljuje s djecom, nailazi na nerazumijevanje ljudi, stradava nakon intervencije vojnog aparata i, na kraju, uskrsava iz mrtvih te uzlazi na noćno nebo. Ako taksativno popišemo i tendenciozno ulančamo epizode filma - prepoznajući fabularni obrazac i uputu za tumačenje u imenu Carpenter koje tuđinac preuzima - onda možemo zaključiti da se izgledno radi o alegoriji »s predumišljajem «. ${ }^{4}$

b) Alegoriju možemo smatrati prvenstveno recipijentovim - odnosno čitateljevim ili gledateljevim - ostvarenjem. U skladu s tim, mogli bismo reći da je alegoreza nužan modus svakog tumačenja koje nadilazi puku filološku analizu. U našem slučaju, to bi svaki znanstveno-fantastični tekst činilo alegorijom: znanstveno-fantastični svjetovi upućivali bi na naš svijet, ali s puno manjom strogošću - ne bi svakom bitnom elementu s doslovne razine značenja morao odgovarati element na prenesenoj razini značenja, što bi pridonijelo povećanju plastičnosti autorske kreacije i čitateljske interpretacije. Ovaj tip shvaćanja, koji prvenstvo daje čitatelju, čini normu pristupa znanstveno-fantastičnim tekstovima (književnim djelima, stripovima i filmovima). O plastičnosti znanstveno-fantastičnog teksta plodonosnog za alegorezu najbolje svjedoči film Matrix (The Matrix, 1999). Filozofi, teoretičari i kritičari najrazličitijih provenijencija u filmu sestara Wachowski vidjeli su ekranizaciju i oprimjerenje pojmova razvijenih $u$ okviru vlastitih pristupa, makar ti pristupi inače počivali na različitim metafizičkim i metodološkim polazištima, bili nesravnjivi, a ponekad i međusobno suprotstavljeni. ${ }^{5}$ Među bezbroj interpretacija Matrixa izdvojit ću onu Jonathana Bellera.

Jonathan Beller, teoretičar koji baštini tradiciju frankfurtske škole, Matrix čita kao da je u pitanju djelo »socijalnog realizma Prvog svijeta« (Beller, 2006:259). Po njegovu mišljenju, film

»... opisuje situaciju u kojoj je percepcija utkana izravno u proizvodnju i u kojoj je imaginacija tehnikom upregnuta da radi protiv interesa svog biološkog domaćina. No biomoć stalno prijeti kapitalu razvojem vlastite svijesti te ta svijest mora biti rastočena unutar umjetne inteligencije.« (Beller, 2006:259)

Dakle, sukob ljudi i strojeva te način na koji je on artikuliran trebamo tumačiti kao klasni sukob u postmodernom razdoblju koje napreduje prema stanju koje je Marx nazvao stvarnom supsumpcijom rada pod kapital. ${ }^{6}$ Matrix sadrži puno više elemenata od potrebnog za korespondenciju do koje je Belleru stalo, zbog čega se film - osim ovom tumačenju - lako otvara i za mnoga druga. Ukratko, on nije alegorija »s predumišljajem«, ne sadrži jednoznačnu autorsku uputu za interpretaciju, već iskorištava sklonost ljudi da u znanstveno-fantastičnom svijetu prepoznaju vlastiti svijet na temelju izomorfnosti nekih odnosa prisutnih u oba svijeta.

\subsection{Znanstvena fantastika kao filozofski alat}

Filozofija može instrumentalizirati znanstvenu fantastiku i na druge načine. Slijedeći Erica Schwitzgebela (2015), mogli bismo čak reći da znanstvena fantastika ima nezaobilaznu ulogu u filozofiranju. Tu je tvrdnju moguće opravdati pozivajući se na srodnost misaonih eksperimenata i znanstveno-fantastičnih 
scenarija. Misaoni eksperimenti po svojoj su naravi fikcionalni scenariji u jezgrenom obliku. ${ }^{7}$ Mnogi se filozofi njima služe. Derek Parfit naročito je poznat po upotrebi fikcionalnih scenarija znanstveno-fantastične naravi. Kratko ću razmotriti samo Parfitov eksperiment čija je pretpostavka da je jedna moždana hemisfera u potpunosti sposobna preuzeti funkciju druge moždane hemisfere. Parfit je zamislio da ima dva brata blizanca. Njih trojica stradaju u nesreći, pri čemu je Parfitovo tijelo nepopravljivo stradalo, ali mu je mozak ostao nedirnut. Njegova su dva brata doživjela drugačiju sudbinu: njima je mozak nepopravljivo oštećen, ali su im tijela ostala zdrava. Parfit kaže ovako:

»Moje tijelo, kao i mozgovi moje braće, nasmrt su oštećeni. Moj je mozak potom raspolovljen i svaka je polovica uspješno presađena u tijelo koje je pripadalo jednom od moje braće. [Nakon transplantacije] oba nova čovjeka vjeruju da su ja, sjećaju se mog života, imaju moju narav i na svaki drugi način stoje u psihičkom kontinuitetu sa mnom. I oba imaju tijelo koje je vrlo nalik mojemu.« (Parfit, 1984:254-255)

Parfit nije znanstveno-fantastični pisac i ne pita se previše kako bi to bilo da svaka od tih osoba mora živjeti u svijetu gdje postoji još jedna osoba koja ima njezine obveze prema prošlosti i, po svemu sudeći, njezina očekivanja od budućnosti. Njega ne zanima istraživanje praktičnih posljedica ovakvog scenarija. Kao filozof, Parfit zanemaruje pitanja te vrste i, za razliku od znanstveno-fantastičnog pisca, pokušava utemeljiti opisani scenarij u postojećim

Redatelj Wise bio je iznenađen religijskom interpretacijom filma. Uz to, treba napomenuti da se ovaj film, bez obzira na moguću autorsku namjeru, gledao i tumačio u različitim kontekstima i na različite načine, ponekad uz potpuno izostavljanje religijskog motivskog sklopa.

Slavoj Žižek opisuje zatečeno stanje prije vlastitog pokušaja povezivanja psihoanalitičke i ideološko-kritičke analize Matrixa: »Moji prijatelji lakanovci upozoravaju me da su autori morali čitati Lacana; pristalice frankfurtske škole u Matrixu vide utjelovljenje same Kulturindustrie, otuđeno-postvarenu socijalnu Supstancu (Kapital), kako direktno preuzima i kolonizira sam naš unutarnji život, koristeći nas kao izvor energije; 'njuejdžeri' u njemu vide izvor spekulacija o tome kako je naš svijet samo ogledalo, proizvedeno globalnim Umom čije je utjelovljenje World Wide Web. Ovi nizovi sežu natrag sve do Platonove Države: zar Matrix doslovce ne ponavlja Platonovu prispodobu o spilji (obični ljudi kao zatočenici, čvrsto vezani za svoja sjedišta i prisiljeni promatrati igru sjenki za koju pogrešno smatraju da predstavlja stvarnost)?« (Žižek, 2008:135-136)

Beller tumači Matrix vrlo slično načinu na koji njegov mentor sa Sveučilišta Duke, Fredric Jameson, tumači pionirski roman kiberpanka Neuromancer. Gibsonovo znanstveno-fantastično remek-djelo Jameson vidi kao paradigmatski primjer načina na koji kapitalizam strukturno uvjetuje kulturnu proizvodnju. Ukratko: Jameson smatra da znanstvena fantastika ne može zamisliti budućnost, već da djela pripadna tom žanru - upravo suprotno od standardne predodžbe - najbolje izražavaju našu nemogućnost da ocrtamo konture budućnosti koja ne bi nalikovala sadašnjosti. Sukladno tome, on Neuromancera čita kao tehnološku ekstrapolaciju kasno-kapitalističke budućnosti izvršenu na temelju kasno-kapitalističke sadašnjosti (Jameson, 2015:221237).

Filozofkinja uma Susan Schneider ovako određuje filozofske misaone eksperimente i njihovu vezu sa znanstveno-fantastičnom književnošću: »Filozofski misaoni eksperiment hipotetska je situacija u 'laboratoriju uma'. Njima se uprizoruju pojave koje često nadilaze granice postojeće tehnike ili su čak nekompatibilne sa zakonima fizike, ali koje bi nam svejedno trebale rasvijetliti temu od filozofske važnosti. Misaoni eksperimenti mogu demonstrirati poantu, zabavljati, ilustrirati zagonetku, raskrinkati proturječje u mišljenju ili nas pozvati da ponudimo pojašnjenje. (...) Ako čitate znanstveno-fantastične pisce poput Stanislawa Lema, Isaaca Asimova, Arthura C. Clarkea ili Roberta Sawyera, onda već znate da su neke od najboljih znanstveno-fantastičnih priča zapravo dugačke verzije filozofskih misaonih eksperimenata.« (Schneider, 2010:14-15) 
pojmovima. Pita se kakvo svjetlo zamislivost scenarija takve vrste baca na problematiku osobnog identiteta. Parfit smatra kako ne bilo pošteno reći da u ovome slučaju nitko više nije identičan originalu. No logika identiteta zabranjuje da obje osobe budu original, a reći da jedna osoba zadržava identitet na štetu druge bila bi tek arbitrarna odluka. Pitanja identiteta, smatra Parfit, mogu imati neodređene odgovore i bilo koja teorija koja implicira kako pitanja identiteta ne mogu imati neodređene odgovore mora biti pogrešna. Zato neredukcionistički pogled na osobni identitet, koji implicira upravo to, mora biti pogrešan. Krajnja je posljedica ovog misaonog scenarija znanstveno-fantastične naravi ta da je preživljavanje odnosno psihički kontinuitet bitan, no $\mathrm{da}$ - za razliku od psihičkog kontinuiteta - osobni identitet nije pojam od presudne važnosti, kao što smo ranije bili skloni misliti. U svakom slučaju, nije od presudne važnosti za teoriju, a možda nije ni za praksu. ${ }^{8}$

Što radi Parfit? On misaonim eksperimentom ne ilustrira već formuliranu teoriju, već se njime služi za formuliranje nove teorije (redukcionistički pogled na osobni identitet) koja je, po njegovu mišljenju, bolja od stare (neredukcionistički pogled na osobni identitet) i trebala bi je zamijeniti. Ovo je, ukratko, primjer »konstruktivnog « misaonog eksperimenta. Lako bismo mogli pronaći primjere »destruktivnih« misaonih eksperimenata koji ne predlažu nove teze $\mathrm{i}$ ustanovljavaju njihovu valjanost, već samo nastoje opovrgnuti postojeće teze (npr. Brown \& Yiftach, 2019). Ta rudimentarna klasifikacija misaonih eksperimenata počiva na pretpostavci da možemo nešto naučiti o stvarnosti samo zamišljajući scenarije koji, kako smo vidjeli, ne moraju biti ograničeni našim tehničkim mogućnostima, znanstvenim spoznajama, a možda čak ni temeljnim prirodnim zadanostima poput zakona fizike. Zasad, jedini je istaknuti kriterij za legitimnost misaonih eksperimenata njihova zamislivost, tj. neproturječnost. Specificiranje odnosa između zamislivosti i mogućnosti zasebno je pitanje čija artikulacija nadilazi problematiku ovog teksta. ${ }^{9}$

Možemo bez kontroverzi zaključiti da je barem neke filozofske probleme poželjno, a možda i nužno, uobličiti služeći se misaonim eksperimentima. Ako je njih barem nepoželjno, ako ne i nemoguće, odstraniti iz filozofskih rasprava, onda moramo odlučno napustiti prilično karikaturalnu ideju filozofije kao isključivo apstraktne argumentacije od koje smo krenuli. Filozofsko rezoniranje mogli bismo točnije, premda provizorno, predstaviti kao kontinuum čija su sredstva zapisivanja logička notacija na jednom kraju, s misaonim eksperimentima negdje po sredini, i dugim pripovjednim tekstovima na drugom kraju. Ako je ta gruba predodžba točna, onda možemo zaključiti da u okviru filozofskog mišljenja duge znanstveno-fantastične priče, neovisno o svim svojim drugim učincima, mogu povremeno odigrati ulogu koja obično pripada koncizno izloženim misaonim eksperimentima.

\section{Znanstveno-fantastični scenarij: $e X i s t e n Z$}

Film Davida Cronenberga eXistenZ nije se posebno istaknuo u kontekstu svog nastanka. U kinima se pojavio gotovo paralelno s Matrixom, tematski sličnim filmom, ali je bio daleko lošije primljen od strane publike i kritike. U Cronenbergovu bogatom opusu on je shvaćen kao faličniji nastavak redateljeva istraživanja problematike otvorene filmom Videodrome (Videodrome, 1983). No relativno loša recepcija eXistenZa ne bi nas trebala odvratiti od analize. Film nudi pronicljivu analizu i kritiku društvenog konteksta u kojem je snimljen, ali on ujedno taj kontekst nadilazi svojim simboličkim viškovima. 
Radnja filma odvija se u bliskoj budućnosti. Računala mogu generirati vrlo kompleksne simulacije i učiniti ih neraspoznatljivim od naše iskustvene stvarnosti. Simulacije, kao i danas, koristi prvenstveno industrija videoigara. No za razliku od trenutnog stanja, za igranje se ne koriste računalni terminali, već organske igraće konzole koje su spojene na tijela igrača preko bio-priključaka. Protagonisti su Cronenbergova filma Allegra Geller i Ted Pikul. Allegra je glasovita programerka koja je dizajnirala videoigru eXistenZ. Ted je pripadnik osiguranja kojega Allegra uvlači u svoj svijet, doslovno i figurativno, nakon što je na nju izvršen atentat. Polako otkrivamo pojedinosti o političkom kontekstu budućnosti koji prijeti našim protagonistima. Allegra i Ted kreću se dvama ukrštenim bojištima: na jednom se sukobljavaju korporacije za proizvodnju i distribuciju videoigara, a na drugom igrači i realisti, odnosno protivnici videoigara, koji smatraju da videoigre treba zabraniti jer podrivaju granicu između realnosti i njezine simulacije. Realisti imaju dobre razloge za militarizaciju. Život protagonista ugrožen je, ali se i njihovo mentalno zdravlje - kako postupno otkrivamo - također narušava u skokovima iz stvarnosti u videoigru i nazad. Zbog prožimanja svijeta nultog stupnja i svjetova viših stupnjeva, odnosno stvarnosti i videoigara, skeptička noćna mora polako se obistinjuje pred očima igrača. Tedu i Allegri sve je teže ustanoviti gdje su, što rade i zašto to rade. Na kraju filma, čini se da su videoigra eXistenZ i ono što smo smatrali stvarnošću nultog stupnja oboje bili ugrađeni unutar videoigre transCendenZ. No zapravo više ne znamo što gledamo. Na kraju nema nikakvog jamstva da protagonisti nisu izašli iz jedne u drugu videoigru, kao ni da nisu oduvijek u videoigri. Nemoguće je zaustaviti skeptički beskonačni regres i dokopati se čvrstog tla.

U nastavku teksta iz eXistenZa, koji shvaćam kao znanstveno-fantastični scenarij, otvorit ću dvije teme. Najprije, (1) bavit ću se prenesenom razinom značenja na kojoj se film ukazuje kao kritika društva u kojem je snimljen: Cronenberg smatra da život u kasnom kapitalizmu biva organiziran sukladno logici igre, da se u takvom životu dragovoljno odričemo upotrebe vlastite slobodne volje i da smo time značajno osiromašeni. Nakon što predstavim problem sa slobodnom voljom u okviru ovog dijegetskog svijeta i tumačenjem toga motiva osvijetlim Cronenbergov 'egzistencijalistički' nazor o suvremenom društvu, otisnut ću se izvan okvira dijegetskog svijeta i samu slobodnu volju predstaviti kao problem. Nisam, za razliku od Cronenberga, uvjeren da su slobodna volja i s njom povezana moralna odgovornost u krajnjoj liniji koherentni pojmovi. Potom, (2) vratit ću se na doslovnu razinu značenja. Cronenbergov znanstveno-fantastični scenarij osuvremenjena je verzija klasičnog skeptičkog scenarija: Ted i Allegra, protagonisti, na kraju više nisu sigurni jesu li u jednoj videoigri, nekoj drugoj videoigri ili stvarnosti, budući da razlika između stvarnosti i videoigre može, ali uopće ne mora biti raza-

Derek Parfit o utjecaju rekonceptualizacije osobnog identiteta na svakodnevnu praksu piše: »Moj život činio mi se [ranije] kao stakleni tunel kroz koji sam se iz godine u godinu kretao sve brže i na kraju kojeg je bio mrak. Kad sam promijenio perspektivu, zidovi od stakla su nestali. Sad se zrak raščistio. Još uvijek postoji razlika između mog života i života drugih ljudi. No razlika je manja. Drugi ljudi su mi bliži. Manje sam zaokupljen vlastitim životom, a više životima drugih ljudi.« (Parfit, 1984:251)

9

Upućujem na zbornik radova Conceivability and Possibility koji su uredili Tamas S. Gendler i John Hawthorne. Moj je stav o odnosu zamislivosti i mogućnosti najbliži Chalmersovu (2002:145-200). 
znatljiva. Tragat ću za metafizičkim pretpostavkama dijegetskog svijeta koji je ispresijecan različitim razinama stvarnosti.

\subsection{Slobodna volja u dijegetskom svijetu eXistenZa}

\subsubsection{Problemi sa slobodnom voljom}

U kakvom se svijetu nalaze Allegra i Ted kad spoje igraće konzole na bio-priključak? Kako bih preciznije opisao taj svijet, posegnut ću za već prihvaćenom Chalmersovom (2017:312) nomenklaturom i neznatno je modificirati. Imerzivnom okolinom nazvat ću okolinu koja generira perceptualni doživljaj okoline iz perspektive unutar te same okoline, pružajući tako korisniku osjećaj »da je stvarno tamo«; interaktivnom imerzivnom okolinom nazvat ću imerzivnu okolinu u kojoj korisnikovo djelovanje može imati značajne i zamjetljive posljedice; virtualnom stvarnošću imenovat ću interaktivnu imerzivnu okolinu koja je računalno generirana (Chalmers, 2017:312). Dakle, »Matrica« $\mathrm{i}$ »XistenZ« bile bi virtualne stvarnosti - u oba slučaja protagonisti ovih dijegetskih svjetova uronjeni su u računalno generiranu okolinu i njihovo djelovanje utječe na objekte koje susreću. No ono što razlikuje Matrix od eXistenZa narav je protagonistova djelovanja u pripadnoj virtualnoj stvarnosti: »Matrica« korisniku pruža iluziju slobodne volje prilikom djelovanja, zbog čega ću je nazvati jakom virtualnom stvarnošću, dok »eXistenZ«, koji povremeno narušava tu iluziju, nazivam slabom virtualnom stvarnošću. Slabu virtualnu stvarnost sačinjavaju epizode unutar kojih korisnik uglavnom vjeruje da je njegovo djelovanje slobodno, no te su epizode povezane dijelovima unutar kojih je to vjerovanje suspendirano, odnosno u kojima je slobodna volja prokazana kao iluzija. Slaba virtualna stvarnost nalikuje videoigrama: korisnik uglavnom upravlja svojim likom u videoigri, koji je modeliran po njegovu biološkom tijelu, no prelazak s jedne na drugu razinu često je povezan epizodama u kojima je lik i dalje prisutan, ali njime ne upravlja korisnikov um, već generator videoigre. Pogledajmo zato kakvi se problemi sa slobodnom voljom otvaraju u ovom svijetu.

Cronenbergov dijegetski svijet počiva na razlici između stvarnosti nultog stupnja, u kojoj protagonisti žive, i slabe virtualne stvarnosti koja je zamišljena kao videoigra te, sukladno tome, protagonisti ulaskom u nju postaju igrači. U okviru ovoga dijegetskoga svijeta, razlika između stvarnosti i igre polako se urušava. To je motiv koji zaslužuje našu pozornost. U uvodu teksta rekao sam da je eXistenZ zanimljiv kao artikulacija straha od toga da društvo sve više nalikuje videoigri. Zadržimo se na toj tvrdnji.

Strah je »uznemirenost izazvana predodžbom o predstojećem zlu koje nas može uništiti ili nam može pričiniti patnju « u kombinaciji s percepcijom da je to zlo »tako blizu da se čini neizbježnim« (Aristotel, 2008:125). U našem kompliciranom svijetu ne možemo se baš oslanjati na strah koji počiva na instinktu kao urođenom filogenetskom odgovoru na opasnost, već moramo ozbiljno razmišljati o tome što nam prijeti. Prijetnje našoj dobrobiti mogu biti nejasne, rasplinute, komplicirane te nam priče - stvarnost ili fikcija - pomažu da ih izoštrimo. Strah, vidimo već po Aristotelovu određenju, potiče na pripovijedanje. On će kod ljudi biti pobuđen samo ako se ljudima uvjerljivo predoči neki događaj ili proces kao nešto što je od velikog značaja za njihov opstanak ili dobrobit, ako ih se uvjeri da će brzo osjetiti posljedice tog procesa i, u konačnici, ako ih se natjera da pomisle kako je stanje izmaknulo kontroli i kako nevolju ne mogu tako lako sami izbjeći. Cronenberg, na samom prijela- 
zu milenija, kao ozbiljnu prijetnju vidi jedan apstraktan proces i pokušava ga konkretizirati upotrebom visceralnih slika. On ljudima predstavlja činjenicu da njihovi životi sve više nalikuju videoigrama, a oni sami igračima. Zašto bi to bilo problematično? Zašto bismo od života trebali očekivati da bude više od videoigre, a od ljudi da budu nešto više od aktivnih igrača ili, još gore, pasivnih likova u videoigrama?

Iako ljudi, po Cronenbergovu mišljenju, imaju slobodnu volju, u videoigrama ne djeluju slobodno. Nakon pokretanja videoigre, odnosno ulaska u njezin svijet, igrač misli da slobodno djeluje, no zapravo nastavak njegova djelovanja, odnosno napredovanje u videoigri, ovisi o tome da se odrekne slobode:

»Računalne igre uče nas strukturirati misli - preoblikuju našu percepciju - tako što nas tjeraju da internaliziramo logiku programa. Kako biste pobijedili ne možete jednostavno činiti što želite. Morate shvatiti što funkcionira unutar pravila igre. Morate naučiti predviđati posljedice svakog poteza i anticipirati odgovor kompjutora. Konačno, vaše odluke postaju intuitivne, glatke i brze poput samih kompjutorskih makinacija.« (Friedman, 1998:136)

Kao igrač, možete čitavo vrijeme misliti da djelujete samostalno i slobodno, no vašim djelovanjem zapravo upravlja, ili ga samo usmjerava, generator igre o čijem funkcioniranju, i svrsi, ne morate ništa znati. Vi ste istodobno igrač koji odlučuje što čini u svijetu igre i igračka u rukama njezinog dizajnera. Može se uzeti da videoigre mogu pružiti užitak zato što u njima možemo slobodno djelovati, no užitak igranja rezultat je neslobode, suspenzije mogućih poteza i pronalaska baš onog rješenja koje se od nas zahtijeva i koje nam omogućuje napredovanje. Nije problem u tome što smo takvi kao igrači. Problem je u tome što nas društvo kao takve građane interpelira. Problem nastaje onda kad se načela po kojima je organizirana računalna igra uvode u područja koja bi trebala biti organizirana sukladno nekim drugim načelima. Jedno od područja u kojem je gamifikacija uzela maha je, primjera radi, obrazovanje. Cronenberg je prijetnju gamifikacije društva osjetio, predočio i satirički kritizirao. Pogledajmo scenu s konobarom koja je paradigmatska za našu alegorijsku interpretaciju.

Ted, protagonist $e X i s t e n Z a$, igrač koji jedva da razumije igru u kojoj sudjeluje, polako postaje svjestan njezinih pravila, odnosno ograničene uloge slobodne volje u njoj. Spoznao je da virtualna stvarnost funkcionira po drugačijim pravilima od stvarnosti nakon susreta s bićima koja se na prvi pogled doimaju kao ljudi sa slobodnom voljom, ali su zapravo automati koji se aktiviraju prema unaprijed zadanom scenariju nakon što detektiraju određene fraze ili djelovanja. Primjerice, jedan od likova kojeg Ted i Allegra susreću u igri konobar je uhvaćen u svojoj petlji dok ne čuje ključne riječi koje ga pozivaju na djelovanje.

Cronenbergov konobar predstavlja savršeno utjelovljenje Sartreova konobara. Sartre uzima savršenog konobara kao biće-po-sebi, odnosno kao objekt lišen samosvijesti i djelatne moći. Čovjek, biće-za-sebe, ne može postati idealni konobar, ali ga može oponašati. Sam pojam oponašanja počiva na nesvodljivoj razlici između čovjeka kao glumca i uloge koju on namjerava odigrati:

»(Konobar) je za druge i za mene predodžba, što znači da ja mogu biti on samo u predodžbi. Ali i radi se o tomu da, ako si ga predočujem, onda ja nisam on, odvojen sam od njega kao subjekt od objekta, odvojen ničim, no to ništa me odvaja od njega, ja ne mogu biti on, ja se samo mogu igrati da jesam on. To jest zamišljati sebi da jesam on.« (Sartre, 2006:94)

Cronenberg je vlastiti film nazvao »egzistencijalističkom propagandom« (Cronenberg, 1999:10). Susret Teda kao slobodnog bića s neslobodnim, pro- 
gramiranim bićem unutar računalne simulacije daje nam ključ za razumijevanje te kriptične deklaracije. Mark Fisher (2012), koji Cronenbergov film vidi dominantno kao alegoriju komunikativnog kapitalizma, ovako tumači susret čovjeka kao bića-za-sebe s ROM-konstruktom kao bićem-po-sebi:

»Da biste cijenili suvremene rezonance eXistenZa, nužno je povezati manifestnu temu umjetne i kontrolirane svijesti s latentnom temom djela. Čemu nalikuju prizori likova zatočenih u nevoljne bihevioralne petlje ako ne pozivnim centrima u svijetu rada dvadeset i prvog stoljeća? U pozivnim centrima se od svih zaposlenika očekuje kvaziautomatizam. Čini se da je prešutni uvjet zaposlenja u njima to da se odreknete subjektivnosti i postanete tek biojezični ekstremitet čiji je zadatak ponavljanje niza fraza koje predstavljaju izrugivanje bilo čemu što bi imalo nalikovalo razgovoru. Razlika 'interakcije' s ROM-konstruktom i 'bivanja' ROM-konstruktom zgodno se preslikava na razliku između zvanja pozivnog centra i rada u pozivnom centru.« (Fisher, 2012:72) $)^{10}$

Tedova nelagoda prilikom susreta $\mathrm{s}$ automatiziranim konobarom zapravo bi bila, alegorijski gledajući, transponirana nelagoda bilo kojeg čovjeka prilikom susreta s nekim drugim čovjekom u našem svijetu koji, zbog zahtjeva radnog mjesta u uslužnim djelatnostima, postupno postaje manje od čovjeka. U gamificiranom društvu sretni smo ako smo barem donekle aktivni igrači (koji npr. zovu pozivni centar) jer nas, ako nemamo sreće, lako može dopasti da budemo pasivni likovi (koji rade u pozivnom centru). Možda je jaz između nas i uloge koju smo prisiljeni odigrati nemoguće potpuno zatvoriti, ali ga je sigurno moguće smanjivati. Cronenberg upozorava na smanjivanje tog jaza. On prikazom problema ne može riješiti taj problem. Riječ je, kako sam kaže, tek o »propagandi« ili agitaciji za pokušaj njegovog rješavanja.

Tedovu spoznaju o naravi igre dodatno je produbilo jezovito otkriće da se njime može djelovati, kao da je alat, bez obzira na njegovu volju. Prilikom interakcije s jednim likom, Ted je na vlastito iznenađenje zavikao »Tebe se ne tiče tko nas je poslao. Tu smo i to je to!«. Šokiran svojim ponašanjem, priznao je Allegri da nije namjeravao to učiniti. Ona je, kao dizajnerica igre, znala da se u tom trenutku igra poigrala njime. Objasnila mu je da neke rečenice moraju biti izrečene tako da bi se radnja razvila i uspostavili likovi te da one bivaju izrečene neovisno o željama igrača. Allegra, marioneta koja vidi svoje konce u ovoj stvarnosti, savjetuje svom suigraču da se ne opire, a njemu ne preostaje ništa drugo nego da sumorno primijeti kako nema nikakve razlike opirao se on »prisilama igre« ili ne. Zanimljivo je kako su artikulirani problemi u ovom dijegetskom svijetu: u stvarnosti je Ted »osuđen da bude slobodan « (Sartre, 1964:25), dok je u virtualnoj stvarnosti ta osuda privremeno suspendirana. Cronenberg na zanimljiv način, unatoč tome što svoj film deklarira kao egzistencijalističku propagandu, skreće pozornost na začudnost Sartreove formulacije. Njegovi likovi imaju problem sa slobodnom voljom, ali se nama - gledateljima njegovih filmova - sama slobodna volja zbog scenarističke nedorečenosti može ukazati kao problem.

\subsubsection{Slobodna volja kao problem}

Što bi značilo da smo osuđeni na slobodu? To bi značilo da smo slični protagonistu filma: Ted Pikul čovjek je nalik nama koji živi u svijetu nalik našemu. Ne znamo je li taj svijet u potpunosti kauzalno zaključen, odnosno je li sve što se u njemu događa determinirano onim što se dogodilo ranije. Ted se našao pred izborom: pomoći osobi u nevolji i riskirati vlastitu sigurnost ili joj ne pomoći i skloniti se na sigurno? Njegov izbor i tjeskoba koja mu prethodi stvarni su. Razmišljajući kasnije o svom činu, on je mogao - sukladno lekci- 
jama (meta)fizike - reći da se dogodilo ono što se moralo dogoditi sukladno strogom uzročno-posljedičnom lancu kojemu se njegov izbor, kao i sve ostalo na ovome svijetu, nužno podvrgava. Međutim, determinizam je objektivni pojam koji se ne da iskusiti, dok su iz njegove subjektivne perspektive prvog lica - koja podrazumijeva iskustvo - čin izbora između alternativa i tjeskoba kao afekt koji prati taj izbor nezaobilazni. Ted se kao čovjek, odnosno kao biće-za-sebe, s njima morao suočiti i u tom je smislu osuđen na slobodu.

Dijaloška razmjena protagonista eXistenZa u pogledu slobodne volje naročito je zanimljiva. Ted, nakon susreta s automatiziranim bićima u svijetu virtualne stvarnosti, primjećuje:

»Slobodna volja... očito ne igra veliku ulogu u ovom našem malom svijetu.»

Allegra mu odgovara:

»Isto je kao u stvarnom svijetu. Imamo je taman toliko da nam bude zanimljivo. ${ }^{11}$

Njezin je odgovor dvosmislen i otvoren raznim tumačenjima. Izvjesno je jedino da Allegra smatra kako u stvarnosti nultog stupnja, koja nalikuje našoj stvarnosti, slobodna volja nije neproblematična. Što bi to moglo značiti? Vratimo se na Teda. Je li on, prije nego što uđe u virtualnu stvarnost, u krajnjoj liniji odgovoran za vlastito djelovanje? To je još jedno pitanje postavljeno pred gledatelje ovog filma, no na njega nije dan odgovor. Smatram da Ted, čija je situacija usporediva s gledateljevom, u krajnjoj liniji nije odgovoran za vlastite izbore $\mathrm{i}$ da to nema veze s time živimo li ili ne živimo u determinističkom svijetu. Takvo su mišljenje u svom radu zastupali, među ostalima, Schopenhauer i Nietzsche, a od naših ga je suvremenika najsustavnije i najkonciznije branio Galen Strawson. Predstavit ću »osnovni argument« pomoću kojega se tvrdi da slobodna volja, a posljedično ni moralna odgovornost, ne postoje. Njega je Strawson (2010:291-292) formalizirao u četiri koraka: ${ }^{12}$

»(1) Činite ono što činite - u okolnostima u kojima se zateknete - zato što ste takvi kakvi ste.

(2) Da biste ste $u$ konačnici bili odgovorni za ono što činite, tad biste u konačnici također morali biti odgovorni - barem po ključnim mentalnim značajkama - za to što ste takvi kakvi ste.

(3) No ne možete u konačnici biti odgovorni za to što ste takvi kakvi ste u bilo kojem pogledu.

(4) Dakle, ne možete u konačnici biti odgovorni za ono što činite.«

Ključan je treći korak $u$ argumentaciji. Zašto ne biste mogli u konačnici biti odgovorni za to što ste takvi kakvi ste u bilo kojem pogledu? Zato što niste, i ne možete biti, uzrokom samog sebe. Pretpostavimo, sukladno znanstvenim

10

Fisher je zbunjen činjenicom da Cronenberg svoj film naziva egzistencijalističkom propagandom. Svoju analizu interakcije Teda i konobara u okviru igre zaključuje sljedećim riječima: »Sada se eXistenZ ne doima kao egzistencijalistička propaganda, već odlučno antiegzistencijalistički. Slobodna volja nije nesvodljiva činjenica ljudske egzistencije: radio se tek o sekvenci koja nije unaprijed programirana, a nužna je da bi zašila dijelove priče koja je već napisana.« (Fisher, 2018:156-157)

11

Cronenberg je naručio novelizaciju svoga scenarija. Posao je zanatski vrlo dobro odradio Christopher Priest (1999), autor niza znanstveno-fantastičnih romana čija je radnja smještena na razmeđu stvarnosti i njezine simulacije. Dijalog između Teda i Allegre o slobodnoj volji raspisan je na 178. stranici.

12

Strawson argument protiv slobodne volje raspisuje u nizu tekstova nastalih nakon objavljivanja svoje prve knjige. Formalizacija ima najmanje četiri koraka, no može imati i više ovisno o tome koje od premisa Strawson posebno razrađuje, opravdava i brani od prigovora. 
spoznajama, da ste takvi kakvi ste većinom zbog svojeg genskog nasljeđa i, još važnije, ranih iskustava sa skrbnicima koji su oblikovali obrasce vašeg mišljenja i djelovanja. Neporecivo je da za vaše ključne odrednice ne možete biti odgovorni ni na koji način. Kasnije tijekom života ne možete steći krajnju ili konačnu odgovornost pokušavajući promijeniti sebe takve kakvi ste zbog svojeg genskog nasljeđa ili ranih iskustava sa skrbnicima. Zašto ne? Zato što će načini na koji pokušavate promijeniti same sebe i stupanj u kojem se uspijete promijeniti također biti određeni time što ste već takvi kakvi ste zbog raznih faktora od kojih su daleko najvažniji vaše gensko nasljeđe i rana iskustva sa skrbnicima. Dakle, možete se poželjeti promijeniti i doista se promijeniti, no te promjene - kao i bilo koje promjene vašeg karaktera koje ostvarite nakon njih - bit će posredno određene vašim genskim nasljeđem i ranim iskustvima sa skrbnicima.

Osnovni argument najčešće se koristi kad se pokušava zanijekati krajnja moralna odgovornost $u$ pogledu djelovanja, no njegova operativnost nije ograničena na etičku domenu. Pokušajmo ga zato ilustrirati čestim slučajem iz svakodnevice. Krenimo od pretpostavke, slično Schopenhauerovoj, da čovjek može činiti ono što želi, ali da ne može sam tako lako, ili uopće, odrediti što će željeti. Na prvu se čini da to nije istina. Na primjer, recimo da poželite željeti nešto što trenutno ne želite. Uzmimo česti slučaj: recimo da ste lijeni i da vam zdravlje pati; ne želite trčati jer je to teško, ali želite biti osoba koja želi trčati jer uživa u tome. Na jedvite jade krenete trčati i disciplinirano se držite trenažnog programa. U početku je teško, ali ste se polako navukli na trening i, nakon dva mjeseca, ne možete više zamisliti život bez trčanja. Niste željeli trčati, ali ste poželjeli biti osoba koja voli trčanje i želi trčati. Sad doista svaki dan želite trčati. A zašto? Zato što ste nekoć poželjeli biti osoba koja želi trčati. No kako se pojavila ta želja da imate želju? Neznatno preformulirajmo problem: želite da želite nešto što još uvijek ne želite. Pitanje je kako se pojavila želja za željom. Ona je naprosto dana. Možete, naravno, reći da ste poželjeli da imate želju za željom. No time nismo napredovali u analitičkom smislu. Kako to da ste poželjeli da imate želju za željom? Ne možete beskonačno potezati taj argument. U nekom trenutku morat ćete priznati da su barem neke želje naprosto tu. Neke želje vam prethode. Neke želje određuju vas - vaše sebstvo, vaše najintimnije ja - a ne vi njih. Čime su one određene? Nije lako na to pitanje jednoznačno odgovoriti - neke genskim nasljeđem i biološkom konstitucijom, neke prvim odnosima sa skrbnicima, odnosno obiteljskim odgojem, neke normama kulture u kojoj živite. Najopćenitije uzevši - naprosto okolnostima s kojima vi nemate ništa. Bitno je da niste i ne možete u konačnici biti odgovorni za ono što ste, a samim time ni za ono što činite.

Mislim da Cronenbergov film nije samo »egzistencijalistička propaganda«. Umjesto da ostane apologija egzistencijalizma, film poziva na razmišljanje o slobodnoj volji, odnosno otvara pitanja na koja je moguće dati odgovore koji se rezolutno kose s osnovnim postavkama filozofije egzistencije.

\subsection{Skepticizam u dijegetskom svijetu eXistenZa}

\subsubsection{Praktične posljedice skepticizma}

Protagonisti Cronenbergova filma na kraju više nisu znali jesu li u stvarnom svijetu ili virtualnoj stvarnosti. Izgubili su osnovu za razlikovanje stvarnosti od njezinog privida. Radikalni skepticizam za njih je postao mora u krvi i 
mesu. Pogledajmo kako je skepticizam u okviru ovog dijegetskog svijeta od metodološkog postao egzistencijalni problem.

Najprije proširimo terminologiju: slabu virtualnu stvarnost koju zatječemo u Cronenbergovu dijegetskom svijetu nazvat ću igrom; Allegru i Teda, kao posjednike mozgova koji primaju inpute iz igre i šalju outpute nazad u igru nazvat ću igračima. Igračima je u igri dodijeljeno pojedino virtualno tijelo. Veza između mozga i tijela je dvosmjerna: kada god virtualno tijelo igrača primi ulazne podatke u okviru igre, mozak igrača također primi istovrsne osjetilne ulazne podatke, a kad god mozak generira motoričke izlazne podatke, oni su preusmjereni u motoričke organe virtualnog tijela. Ključno je pitanje za protagoniste: kako spoznati da nisu u igri koja savršeno simulira stvarnost i njezine teksture? Protagonisti unutar igre ne mogu sa sigurnošću spoznati da se ne nalaze u igri. Oni ne mogu biti sigurni da trenutno nisu u igri i, još gore, da oduvijek nisu bili u igri. Njihovu nesigurnost u pogledu naravi vlastitog svijeta nazvat ću skepticizmom.

Skepticizam prijeti podrivanju gotovo svega što likovi znaju. Allegra i Ted ne mogu isključiti istinitost skepticizma te on, u slučaju da je istinit, poništava većinu njihovih vjerovanja. Možda su na kraju konačno uspjeli izaći iz igre, no - kako sugerira zadnja scena - ne mogu isključiti mogućnost da su još uvijek u njoj, uslijed čega bi većina njihovih vjerovanja bila lažna. Skepticizam ih navodi na sumnjičavost u pogledu većine njihovih vjerovanja: oni vjeruju u puno toga, ali ne znaju - strogo govoreći - jesu li ta vjerovanja istinita. Dakle, oni ne znaju puno toga što su mislili da znaju.

Kako mi, gledatelji eXistenZa, znamo da naša stvarnost nije simulacija u kojoj gledamo film o dvama likovima koji su zarobljeni u simulaciji? Zapravo ne možemo tako lako odbaciti takvu mogućnost. Mogućnost da živimo u skeptičkom scenariju epistemološki je poligon za testiranje naših spoznajnih teorija. Cilj je razviti teoriju koja bi delegitimirala pretpostavke skepticizma. Skepticizam, kako vidimo, u okviru filozofije ima metodološku važnost. No on nema egzistencijalnu, odnosno praktičnu važnost - svakodnevni život većine ljudi, uključujući profesionalne filozofe, nije se nimalo promijenio nakon suočavanja s mogućnošću da žive u skeptičkoj noćnoj mori. Razmislimo o razlozima te praktičke beznačajnosti. Pretpostavite da vam netko, poput Morpheusa Neu u Matrixu, kaže da ste u simulaciji. Zašto biste tu tvrdnju uopće uzeli zaozbiljno? Duncan Pritchard (2012:71) kaže da ne biste trebali to učiniti nakon što dvojbu rastavi na slučajeve:

a) Ako se nalazite u simulaciji, onda je istinita 'informacija' o tome da ste u simulaciji dio obmanjujuće struje 'lažnih' doživljaja koja se - u okviru simulacijskog postava - slijeva u vas te biste trebali biti sumnjičavi kad su ti doživljaji u pitanju.

b) Ako se ne nalazite u simulaciji, onda se zasigurno uopće ne biste trebali zamarati ‘informacijom' koja vam je ponuđena jer je ona lažna. U svakom slučaju, bez barem dviju perspektiva - bez mogućnosti da vidite simulacijski hardver koji pokreće savršenu simulaciju u kojoj navodno živite - trebali biste zanemariti 'informaciju' koja vam je ponuđena. Ako ne možemo ustanoviti živimo li u stvarnosti koja odgovara našoj svakodnevici ili u skeptičkoj noćnoj mori, onda je potonja mogućnost samo zanimljiva teorijska razbibriga bez ikakvih praktičnih posljedica.

Cronenbergov film skepticizam kao teorijsku noćnu moru preobražava u egzistencijalnu noćnu moru. Protagonisti filma imaju na raspolaganju dvije perspektive - izvansimulacijsku i simulacijsku - no, kako vrijeme prolazi, 
više nisu sigurni koju od njih trenutno zauzimaju i je li izvansimulacijska perspektiva uopće ono za što se izdaje. Urušava se granica između stvarnosti i njezine simulacije koja joj nalikuje, ali funkcionira po drugačijim pravilima. Protagonisti polako ostaju bez osnove po kojoj bi živjeli bez zadrške jer se u svakom trenutku njihov život može preobraziti iz svakodnevice u bizarni spektakl. Cronenberg uprizoruje prijelaz likova iz stvarnosti u virtualnu stvarnost, postupno urušavanje granice među njima, psihičku apokalipsu takvog urušavanja i problematičnu rekonstituciju društva u svjetlu te apokalipse. Ukratko, njegov film kao dobra znanstveno-fantastična priča predočava kako bi to bilo kad bismo mogli znati da živimo u simulaciji.

\subsubsection{Teorijske posljedice skepticizma}

Sukladno tezi istaknutoj u prvom dijelu teksta, eXisten $Z$ - kao znanstveno-fantastično pripovjedno djelo - možemo smatrati misaonim eksperimentom koji pomaže u izgradnji teorije. Smatram da Cronenbergov film shvaćen kao misaoni eksperiment, međutim, govori u prilog koherentnosti dviju teorija, odnosno da reanimira dvije stare, ali prijeporne filozofske pozicije, a ne jednu: interakcionistički dualizam i transcendentalni idealizam. Skicirat ću vrlo kratko kako on to čini bez upuštanja u detaljnu raspravu o ovim dvama pozicijama.

\subsubsection{Reanimacija interakcionističkog dualizma}

Scenarij eXistenZa prati likove koji iz stvarnosti ulaze u virtualnu stvarnost. Nakon što se ispostavi da je ono što su smatrali stvarnošću nultog stupnja također bila virtualna stvarnost, sami protagonisti - a ni mi kao gledatelji - nisu sigurni u pogledu ontološkog statusa stvarnosti u kojoj su se zatekli neposredno prije završetka filma: je li to stvarnost nultog stupnja ili virtualna stvarnost? Sasvim je moguće da su protagonisti ovog filma, kao i protagonisti filma Matrix, čitav svoj život proživjeli u virtualnoj stvarnosti. Prema toj pretpostavci, većina njihovih vjerovanja - to da imaju tijelo kakvo su mislili da imaju, da žive u gradu i kreću se njime, da je njihov svijet star 4,5 milijardi godina - zapravo je lažna. Jedna od rijetkih izvjesnosti protagonista jest to da postoje. Oni su sigurni u postojanje svojih doživljaja i mogu dovesti u pitanje postojanje svega što doživljavaju, ali ne i sam doživljaj. Bilo bi besmisleno tvrditi kako se samo čini da njihov doživljaj postoji. To da se čini da doživljaj postoji naprosto znači on postoji. Doživljaj upravo jest to čini se, to izgleda, odnosno taj privid; on postoji bez obzira na to jesu li njegovi sadržaji - nebo iznad njih, konferencijska soba, drugi ljudi itd. - »stvarni« ili nisu i bez obzira na to je li išta što oni mogu reći o tim sadržajima istinito ili nije. ${ }^{13}$ Ako postoje doživljaji, onda postoji i subjekt kojima oni pripadaju. Naše pitanje sada izgleda ovako: kakav je odnos između uma subjekta i svijeta koji taj um doživljava?

Po pretpostavci, protagonisti imaju (minimalno) dva tijela. Jedno je tijelo u stvarnosti nultog stupnja, a drugo unutar simulacije te stvarnosti. Mozgovi njihovih tijela u stvarnosti nultog stupnja priključeni su na simulaciju od rođenja. Mozak prima ulazne podatke iz simulacije stvarnosti i šalje izlazne podatke u simulaciju. Dakle, njihov fizički mozak - a posredno i um - u interakciji je s njihovim simuliranim, odnosno nefizičkim tijelima. Ta činjenica eXistenZ čini osuvremenjenom verzijom descartesovskog interakcionističkog dualizma. Što smo dobili s tim osuvremenjivanjem? Interakcionistički dua- 
lizam napadan je na račun nezamislivosti interakcije nefizičkog uma s fizičkim procesima. Ta je kritika neopravdana. Sasvim je zamislivo da bi jedna supstanca - odnosno procesi jedne vrste - mogla biti u interakciji s drugom supstancom - odnosno procesima druge vrste. ${ }^{14}$ Cronenbergov scenarij, tek jedan u nizu sličnih scenarija, zamišlja uzročni model koji bi omogućio takvu interakciju. Ne tvrdim da je taj model jedino, najbolje, ni uopće uvjerljivo rješenje za interakciju uma i tijela u našem svijetu, već samo to da on, barem na prvi pogled, nije nekoherentan. Ne tvrdim čak ni da je savršeno koherentan i da ga nije moguće kritizirati, nego samo to da je teret kritiziranja - i dokazivanja opravdanosti kritika - opet na protivnicima interakcionističkog dualizma.

\subsubsection{2. »Ilustracija« transcendentalnog idealizma po analogij $1^{15}$}

Transcendentalni idealizam pozicija je koja smatra da temeljna priroda našeg svijeta u načelu nije spoznatljiva metodama prirodnih znanosti koje moraju poći od naših opažaja i pretpostaviti kognitivnu strukturu koja uređuje te opažaje. Recimo da smo, sukladno skeptičkom scenariju, čitav život proveli u simulaciji stvarnosti. Nespoznatljiva priroda, ili stvarnost po sebi, mogla bi biti stvarnost onkraj simulacije stvarnosti koju opažamo. Stvarnost po sebi, u načelu, mogla bi biti znatno drugačija od stvarnosti za nas. Ona bi mogla biti implementirana komputacija, a ta implementacija ne bi se morala ostvariti $u$ fizičkom mediju. ${ }^{16}$ Dakle, među ostalim, stvarnost po sebi uopće ne bi morala biti prostorna. To je način da si predstavimo razliku između stvarnosti po sebi i stvarnosti za nas. Po Kantovu mišljenju, ne odnosi se prostor na svojstvo stvari kakve su one po sebi, odnosno neovisno o našim umovima:

»Mi tvrdimo dakle empirijski realitet prostora (u pogledu svakoga mogućeg vanjskog iskustva), ali ujedno i njegov transcendentalni idealitet, tj. da on nije ništa, čim napustimo uvjet mogućnosti svega iskustva, prihvaćajući ga kao nešto što je stvarima samo o sebi osnova.« (Kant, 1984:38)

Stvarnost, promatrana neovisno o kognitivnoj strukturi kojom je posredovana, za nas nije ništa jer nam ta nezavisnost po definiciji nije dostupna.

13

Svi »realisti« u pogledu doživljaja slažu se s ovom poantom. Nju je, primjerice, koncizno sročio John Searle: »Ne možete osporiti postojanje svjesnih doživljaja time što ćete dokazati da su oni prividi ispod kojih je stvarnost, budući da - kad se radi o svijesti - postojanje privida jest stvarnost. Ako mi se čini kao da upravo imam svjesni doživljaj, onda imam svjesni doživljaj.« (Searle, 1997:112)

14

David Chalmers, analizirajući Matrix, dolazi do istog zaključka: »Ponekad se tvrdi kako ideja o međudjelovanju fizičkih procesa s nefizičkim umom nije samo neuvjerljiva, već i nekoherentna. Hipoteza o Matrici navodi nas na to da priznamo kako to naprosto nije istina. Po ovoj hipotezi, naši kognitivni sustavi uključuju procese koji su potpuno drugačiji od procesa u fizičkom umu, no dobivamo jasnu kauzalnu priču o njihovom međudjelovanju.« (Chalmers, 2010:483)
15

Ovdje se oslanjam na tekst Erica Schwitzgebela (2019) koji je, pišući svoj tekst, oslonac našao u Chalmersovu radu: »Matrix je tumačen kao ilustracija mnogih filozofskih ideja: Platonove špilje, Descartesova skepticizma, Berkeleyjeva idealizma itd. Ako sam u pravu, njega je moguće temeljnije tumačiti kao ilustraciju kantovske skromnosti.« (Chalmers, 2010:489)

16

Za spisak nužnih uvjeta komputacije, u koje po autorovom eksplicitnom navodu ne spada njezina implementacija $\mathrm{u}$ fizičkom mediju, korisno je pročitati rad Erica Schwitzgebela »Kant Meets Cyberpunk«: »Hilary Putnam dao je opasku da nema ničega vezano za komputaciju što bi zahtijevalo da bude implementirana u materijalnoj supstanci. U teoriji, mogli bismo izgraditi računalo od ektoplazme (...).« (Schwitzgebel, 2019:421) 
Vratimo se ponovno našim protagonistima: oni imaju simulirana tijela i biološka tijela. Dok su u igri, njihova simulirana - odnosno iskustvena tijela - hodaju prema motelu, a njihova biološka tijela miruju u sobi. Tek kad se isključe iz igre, sa suspenzijom simuliranog tijela, njihova će iskustvena tijela i biološka tijela biti sinkronizirana. Ono »iskustveno« je za protagoniste Cronenbergova dijegetskog svijeta odnosni pojam koji ovisi o prostornoj okolini u kojoj su se zatekli. U Cronenbergovu dijegetskom svijetu imamo posla s barem dvama prostorima: prostorom stvarnosti nultog stupnja i prostorom virtualne stvarnosti. Virtualnu stvarnost možemo smatrati jednim prostornim mnoštvom u kojoj je svaki dio prostorno povezan sa svakim drugim dijelom. Motel prema kojem se Ted i Allegra kreću u igri nije dio istog prostornog mnoštva kao soba u kojoj su se oni uključili u igru. Zamislimo da Teda netko pored motela u igri upita da mu pokaže gdje je soba u kojoj se spojio na igru. Ted ne može odgovoriti na to pitanje jer pitanje nema smisla. Soba u kojoj se Ted spojio na igru nije ni u kakvom prostornom odnosu s motelom. Ne možete rukom pokazati na smjer motela niti propješačiti put od motela do sobe jer motel i soba, uzeti kao sinegdohe, naprosto ne pripadaju istom prostornom mnoštvu. Postoje dva različita prostora koji pripadaju dvama različitim stvarnostima - stvarnosti nulte razine i virtualnoj stvarnosti. Likovi mogu zaključiti da se radi o prilično različitim stvarnostima kojima ne upravljaju isti zakoni. Koliko te stvarnosti - stvarnost po sebi i stvarnost za njih - mogu biti različite?

Istaknute stvarnosti mogu biti potpuno nesumjerljive. Mogu biti toliko različite da gotovo ništa što znamo o virtualnoj stvarnosti - stvarnosti za njih - nije primjenjivo za stvarnost po sebi. U Cronenbergovu scenariju, koji posuđuje motive iz imaginarija kiberpanka, stvarnost nulte razine trebala bi biti nalik našoj izvandijegetskoj stvarnosti. No, što ako je naša izvandijegetska stvarnost, kao i dijegetska stvarnost nultog stupnja, također simulacija? Kakva je temeljna narav stvarnosti nultog stupnja? Kakve je naravi transcendencija? O tome protagonisti, kao i mi, mogu samo nagađati. Protagonisti - koji su preživjeli skeptičku noćnu moru - sumnjaju da bi njihov svijet, u kojem žive od rođenja, također mogao biti simulacija generirana komputacijskim procesima koji konstituiraju mikrofizičke procese u njihovom svijetu. Medij u kojem je komputacija generirana ne mora uopće biti fizički medij. Protagonisti nagađaju o temeljnoj naravi stvarnosti po sebi i njihova bi se nagađanja, s obzirom na to da se radi o temeljnoj razini, mogla odnositi i na narav naše stvarnosti. Uzmimo da je to slučaj: moramo priznati da ništa ne znamo, niti u načelu možemo znati, o temeljnoj prirodi našeg svijeta. Što se nas tiče, možda je naša stvarnost - svijet koji opisuje fizika - rezultat komputacije implementirane u nefizičkom mediju. Stvarnost po sebi, ono što nadilazi naše osjetilno iskustvo, možda nije ni prostorna kao što predviđa idealizam, iako je za nas - bića koja u njoj žive - ona predočiva samo prostorno. To je osuvremenjeni način da se uz pomoć imaginarija kiberpanka predoči nepredočivost stvarnosti po sebi, dakle, jedne od temeljnih lekcija transcendentalnog idealizma.

\section{Zaključak}

Filozofija i znanstvena fantastika kao različiti diskursi na različite načine koriste protuintuitivne scenarije. Filozofija nastupa fundacijski u pokušaju da utemelji protuintuitivne scenarije i dokaže njihovu koherentnost, dok znanstvena fantastika kao transmedijalni fikcionalni žanr pretpostavlja njihovu koherentnost i nastupa pragmatički prilikom pripovijedanja o tome kako bi 
to bilo kad bi se oni obistinili. eXistenZ, znanstveno-fantastični scenarij Davida Cronenberga, predstavlja zanimljiv analitički materijal na prenesenoj i doslovnoj značenjskoj razini: 1) Cronenberg smatra da život u kasnom kapitalizmu biva organiziran sukladno logici igre, predočava tu logiku svojim fikcionalnim scenarijem i prokazuje je kao nepoželjnu; 2) u dijegetskom svijetu eXistenZa likovi postupno otkrivaju da nisu sigurni u pogledu prirode svijeta kojim se kreću. Cronenbergov film predstavlja novu (ali ne i originalnu) artikulaciju skepticizma kao starog filozofskog problema. Pokušaj fundiranja pretpostavki scenarija ovog znanstveno-fantastičnog filma doveo je reanimiranja dviju filozofskih pozicija: kartezijanskog interakcionističkog dualizma i kantovskog transcendentalnog idealizma.

\section{Bibliografija}

Aristotel, Retorika, preveo Marko Višić, Unireks, Podgorica 2008.

Bekavac, Luka, »Teorijske fikcije. Ligotti, Negarestani i spekulativni realizam«, Anafora 3 (2016) 1, str. 1-19.

Beller, Jonathan, Acquiring Eyes. Philippine Visuality, Nationalist Struggle and The World Media-System, Ateneo de Manila University Press, Manila 2006.

Brown, James Robert; Fehige, Yiftach, »Thought Experiments«, u: Edward N. Zalta (ur.), The Stanford Encyclopedia of Philosophy. Dostupno na: http://plato.stanford.edu/archives/ win2019/entries/thought-experiment (pristupljeno 18. 10. 2019.).

Chalmers, David, »Does Conceivability Entail Possibility«, u: Tamar S. Gendler; Hawthorne, John (ur.), Conceivability and Possibility, Oxford University Press, Oxford 2002., str. 145-200.

Chalmers, David, The Character of Consciousness, Oxford University Press, Oxford 2010.

Chalmers, David, »The Virtual and the Real«, Disputatio 9 (2017), br. 49, str. 309-352, doi: https://doi.org/10.1515/disp-2017-0009.

Cronenbeg, David, »Game Boy«, Sight and Sound 9 (1999) 4, intervju (razgovarao Chris Rodley), str. 8-10.

Fisher, Mark, »Work and Play in Existenz«, Film Quarterly 65 (2012) 3, str. 70-73, doi: https://doi.org/10.1525/fq.2012.65.3.70.

Fisher, Mark, K-punk. The Collected and Unpublished Writings of Mark Fisher (20042016), Repeater, London 2018.

Friedman, Ted, »Civilization and its Discontents: Simulation, Subjectivity, and Space«, u: Smith, Greg M. (ur.), On a Silver Platter. CD-ROMs and the Promises of a New Technology, NYU Press, New York 1998., str. 132-150.

Immanuel Kant, Kritika čistoga uma, preveo Viktor D. Sonnenfeld, Nakladni zavod Matice hrvatske, Zagreb 1984.

Jameson, Fredric, »A Global Neuromancer«, u: Jameson, Frederic, The Ancients and the Postmoderns. On the Historicity of Forms, Verso, London, New York 2005., str. 221-237.

Parfit, Derek, Reasons and Persons, Oxford University Press, Oxford 1984.

Pavličić, Pavao, Moderna alegorija, Matica hrvatska, Zagreb 2013.

Priest, Christopher, eXistenZ. A novelization from an original screenplay by David Cronenberg, Harper Collins, New York 1999.

Pritchard, Duncan, »eXistenZial Angst«, u: Simon Riches (ur.), The Philosophy of David Cronenberg, The University Press of Kentucky, Lexington 2012., str. 69-77.

Sanders, Steven M., The Philosophy of Science Fiction Film, The University Press of Kentucky, Lexington 2008. 
Sartre, Jean Paul, Egzistencijalizam je humanizam, preveo Vanja Sutlić, Veselin Masleša, Sarajevo 1964.

Sartre, Jean-Paul: Bitak i Ništo. Ogled iz fenomenološke ontologije, sv. 1, preveo Daniel Bučan, Demetra, Zagreb 2006.

Schneider, Susan, Science Fiction and Philosophy. From Time Travel to Superintelligence, Wiley-Blackwell, Oxford 2010.

Schwitzgebel, Eric, »Philosophers Recommend Science Fiction«, 2015. Dostupno na: https://faculty.ucr.edu/ eschwitz/SchwitzPapers/PhilosophersRecommend-150507-short. pdf (pristupljeno 28. 10. 2019.).

Schwitzgebel, Eric, »Kant Meets Cyberpunk«, Disputatio 11 (2019), br. 55, str. 411-435, doi: https://doi.org/10.2478/disp-2019-0006.

Searle, John, The Mystery of Consciousness, New York Review of Books, New York 1997.

Shaviro, Steven, Discognition, Repeater, London 2016.

Strawson, Galen, Freedom and Belief, Oxford University Press, Oxford 2010.

Suvin, Darko, Metamorfoze znanstvene fantastike, Profil, Zagreb 2010.

Žižek, Slavoj, Pervertitov vodič kroz film, preveli Srećko Horvat et al., Izdanja Antibarbarus, Hrvatsko društvo pisaca, Zagreb 2008.

\title{
Ante Jerić
}

\section{On the Edge of Playability: Existence} and Transcendence in the Movie eXisten Z

\begin{abstract}
Philosophy and science fiction are two separate discourses that use counter-intuitive scenarios in two distinct ways. Where philosophy endeavours to ground counter-intuitive scenarios, science fiction as a transmedial fictional genre acts in a pragmatic and exploratory manner by seeking to imagine what it would be like if they were real. In this paper, I analyse David Cronenberg's science fiction film eXistenZ, and defend two theses. The critical-theoretical thesis: Cronenberg thinks society is being gamified and seeks to dramatise the process of gamification along with its pitfalls. The metaphysical thesis: Cronenberg's diegetic world brings about a new articulation of the scepticism as an old philosophical problem. An attempt to excavate the metaphysical presuppositions of this work reanimates Cartesian interactionist dualism and Kantian transcendental idealism, as two well-known philosophical positions.
\end{abstract}

\section{Keywords}

science fiction, thought experiment, David Cronenberg, scepticism, free will, interactionist dualism, transcendental idealism 